DOI 10.15290/cnisk.2018.01.04.10

\author{
DR MARIA BAUCHROWICZ-TOCKA \\ orcid.org/0000-0003-1691-2568 \\ Uniwersytet w Białymstoku

\section{Łomża i region na łamach prasy łomżyńskiej okresu międzywojennego, ss. 426}

\title{
Streszczenie
}

Autoreferat prezentuje główne zagadnienia przedstawione w rozprawie doktorskiej napisanej pod kierunkiem dr hab. Małgorzaty Dajnowicz, prof. UwB. Ukazuje także przyczyny podjęcia tematu badawczego. Zasadniczy temat rozprawy, wielowatkowy obraz Łomży i regionu w latach 19181939, poprzedza szeroka analiza polskojęzycznej łomżyńskiej prasy okresu międzywojennego, która stanowiła główne źródło badań i analiz. Autorka rozprawy korzystała też $z$ wielu opracowań dotyczacych historii prasy i historii Łomży oraz materiałów archiwalnych (Archiwum Akt Nowych w Warszawie, Archiwum Państwowe w Łomży). Autoreferat przedstawia wykorzystane w pracy źródła, jak również stosowane metody badawcze. Rozprawa doktorska zbudowana jest $z$ siedmiu rozdziałów. Autoreferat prezentuje ich krótka charakterystykę oraz wnioski ogólne zawarte w rozprawie.

Słowa kluczowe: II Rzeczpospolita, historia prasy, historia Łomży, prasa regionalna, praca doktorska

\section{LOMZA AND ITS SURROUNDINGS IN THE LOCAL PRESS DURING THE INTERWAR PERIOD, PP. 426}

\begin{abstract}
The following summary presents the fundamental issues introduced in the doctoral dissertation written under the supervision of Małgorzata
\end{abstract}


Dajnowicz, Professor of the University of Białystok. It explains the reasons for undertaking the research topic. The main subject of the thesis, beign the multi-layered community of Łomża and the region in the years 1918 to 1939 , is preceded by a broad analysis of the Polish-language press issued in Łomża during the interwar period. It was the main source of the research and analysis. The author of the dissertation reffered to numerous studies concerning the history of Łomża and the press as well as to various archival materials (the Central Archives of Modern Records in Warsaw, the State Archives in Łomża). The paper presents references as well as applied research methods. The dissertation consists of seven chapters. The following summary focuses on their brief characteristics and some general conclusions included in the dissertation.

Keywords: Second Polish Republic, press history, history of Łomża, regional press, $\mathrm{PhD}$ dissertation

Łomża okresu międzywojennego pełniła rolę centrum administracyjnego, oświatowego, gospodarczego i kulturalnego w stosunku do ościennych miejscowości. Była też ważnym ośrodkiem życia religijnego. W 1925 r. stała się stolica powołanej przez papieża Piusa XI diecezji łomżyńskiej. W mieście liczacym 25 tys. mieszkańców w latach 1918-1939 (w różnych okresach) wychodziło 29 tytułów prasowych, przez co Łomża stała się znaczącym ośrodkiem prasowym w regionie.

Historia Łomży okresu międzywojennego, chociaż budziła zainteresowanie badaczy różnych dziedzin (historyków, językoznawców, socjologów), dotychczas nie została kompleksowo opracowana. Do tej pory nie powstało także monograficzne opracowanie polskojęzycznej łomżyńskiej prasy międzywojnia. To były główne powody do podjęcia próby przedstawienia obrazu Łomży i regionu dwudziestolecia międzywojennego, zaprezentowania polskojęzycznej prasy tego okresu oraz ukazania jej znaczenia w badaniach historii regionalnej.

Ze względu na skromny i rozproszony zasób źródeł na temat historii ziemi łomżyńskiej w dwudziestoleciu międzywojennym, bo sa to głównie artykuły naukowe, wydawnictwa pokonferencyjne i nieliczne pozycje książkowe dotyczące wybranych zagadnień, głównym materiałem źródłowym moich badań stała się polskojęzyczna prasa wychodząca w Łomży w latach 1918-1939. 
Charakter łomżyńskich pism odzwierciedlał ideologiczny podział ówczesnego społeczeństwa miasta. W Łomży w tym samym czasie wydawane były dwa, trzy, a nawet cztery tytuły o różnym zabarwieniu społeczno-politycznym. Sytuacja ta pozwalała uniknać jednostronnego i niepełnego lub zniekształconego obrazu regionalnych wydarzeń. Ich prezentacja oraz ocena faktów była przynajmniej dwustronna, na podstawie prasy opozycyjnej i prorządowej.

W pracy wykorzystałam publikacje z 49 tytułów prasowych. Zanalizowałam ponad 3000 stron pism (wychodzacych przed 1939 r.), które znajduja się w zbiorach Biblioteki Narodowej i Biblioteki Uniwersytetu Warszawskiego ${ }^{1}$. W badaniach zawartości prasy skupiłam się na analizie treści tekstów. Dokonałam selekcji problematyki, klasyfikując i analizujac publikacje prasowe w kategoriach tematycznych. Przy omawianiu poszczególnych zagadnień stosowałam kompozycję problemowo-chronologiczną. Przyjmując takie metody badawcze, wzorowałam się na opracowaniach prasy historyków i prasoznawców, m.in.: Jolanty Chwastyk-Kowalczyk, Małgorzaty Dajnowicz, Marka Jeleniewskiego, Ewy Maj, Andrzeja Notkowskiego, Wiesława Władyki i innych. Prasowe informacje, na ile to było możliwe, weryfikowałam i poszerzałam, sięgając do opracowań i artykułów. Przeprowadziłam też kwerendy w Państwowym Archiwum w Łomży i w Archiwum Akt Nowych w Warszawie.

Rozprawę tworzą dwie tematyczne części. W pierwszej z nich, która jest pierwszym rozdziałem, przedstawione zostało główne źródło badań, czyli łomżyńska prasa. W tej części, dla ukazania całości zagadnienia, wykroczyłam poza nakreślone ramy chronologiczne i zaprezentowałam historię łomżyńskiego czasopiśmiennictwa do 1918 r. Omówiłam także uwarunkowania prawne funkcjonowania prasy w latach 1918-1939 oraz ukazałam twórców polskojęzycznej łomżyńskiej prasy. Szerzej zaprezentowana została prasa wydawana w Łomży w okresie międzywojennym - 29 tytułów prasowych podzieliłam na 4 kategorie tematyczne: pisma informacyjno-polityczne (10 tytułów), katolickie (8 tytułów), młodzieżowe (8 tytułów) i branżowe (3 tytuły). W kolejnych podrozdziałach w porządku chronologicznym przedstawiałam charakterystyke pism wymienionych kategorii. Opracowałam też tabele, które przedstawiają okresy obecno-

\footnotetext{
1 W czasie kwerendy rozcinałam skalpelem zszyte w drukarni kartki trzech pism: „Tygodnika Łomżyńskiego” (1939), „Ku Szczytom” (1929-1930) i miesięcznika „Młodość” (1928, 1929), co mogło świadczyć, że byłam ich pierwszą czytelniczką.
} 
ści na rynku wydawniczym poszczególnych tytułów i są uzupełnieniem podrozdziałów.

W drugiej, zasadniczej, części dysertacji w sześciu tematycznych rozdziałach przedstawiłam obraz Łomży i regionu, jaki wyłaniał się $z$ prasowych łamów. Rozdziały poświęcone sa: polityce, społeczeństwu, Kościołowi, gospodarce, oświacie i szkolnictwu, kulturze. Każdy z nich, w celu przejrzystego i uporządkowanego przedstawienia zagadnień, podzielony jest na kilka podrozdziałów. Każdy rozdział kończy się podsumowaniem.

Rozdział Społeczeństwo ukazuje działalność władz samorząowych, organizację opieki medycznej i społecznej w mieście, zagadnienie bezrobocia, udział łomżan w wojnie $1920 \mathrm{r}$. $Z$ analizy prasowych artykułów wynikało, iż prasa w pośredni sposób wpływała na decyzje lokalnego samorządu dotyczące różnych kwestii społecznych. W tym rozdziale przedstawione sa także obchodzone w mieście i regionie uroczystości (rocznice, święta, odpusty), opisywane sensacje i skandale obyczajowe, które dopełniły obrazu łomżyńskiego społeczeństwa.

W rozdziale poświęconym polityce przedstawione zostały wydarzenia $z$ krajowej i regionalnej sceny politycznej, które znalazły odzwierciedlenie w łomżyńskiej prasie. Artykuły ukazywały, z jakimi problemami mierzyło się łomżyńskie społeczeństwo w pierwszych latach niepodległości. Pisma przedstawiały zaangażowanie łomżan w wybory parlamentarne. $Z$ treści publikacji wynikało, iż w Łomży byli zwolennicy i przeciwnicy przewrotu majowego Józefa Piłsudskiego. Na łamach prasy ujawniały się ideologiczne podziały społeczeństwa. W tym rozdziale opisałam także wpływ krajowych wydarzeń politycznych na łomżyńską działalność prasową oraz rolę miejscowej prasy w kreowaniu życia politycznego i społecznego w regionie.

O ustanowieniu diecezji łomżyńskiej, ingresach dwóch biskupów, Romualda Jałbrzykowskiego i Stanisława Kostki Łukomskiego, traktuje rozdział poświęcony Kościołowi. Ukazana została jego wiodąca rola w środowisku i polityczna aktywność kapłanów. Księża diecezji łomżyńskiej często przewodzili w regionie strukturom Narodowej Demokracji (np. ks. Antoni Roszkowski był przewodniczacym zarząu okręgu Stronnictwa Narodowego w Łomży, ks. Józef Rogiński przewodniczył w Wysokiem Mazowieckiem, a ks. Piotr Krysiak w Wąsoszu).

Rozwój transportu i komunikacji w regionie oraz zagadnienia inwestycyjne poruszono w rozdziale poświęconym gospodarce. Łomżyńska 
polskojęzyczna prasa nie tylko informowała o bieżących wydarzeniach, lecz także inspirowała do podejmowania działań, a nawet podpowiadała gospodarcze rozwiazania (np. budowę wodociagu, utworzenie w Łomży linii komunikacji miejskiej).

Zaangażowanie społeczeństwa w likwidację analfabetyzmu, budowę i organizację szkół było w Łomżyńskiem niezwykłe. Rozważania na ten temat zawiera rozdział poświęcony oświacie i szkolnictwu. W budowę szkół aktywnie włączali się mieszkańcy wsi, ofiarowując drewno, własną pracę oraz pieniądze. Rozwijało się też szkolnictwo zawodowe. W życie szkoły angażowali się księża, a o zagadnieniach braku szkół i konieczności stworzenia warunków nauki dla wszystkich dzieci z taką samą troską pisała tak prasa katolicka, jak i świecka.

Zagadnieniom kulturalnym w regionie, ciekawej rywalizacji czterech kin w mieście, aktywnej scenie muzycznej i teatralnej, rozwojowi bibliotek oraz o utworzonym przez Adama Chętnika i otwartym w 1927 r. Muzeum Kurpiowskim w Nowogrodzie traktuje ostatni rozdział poświęcony kulturze. Tu warto zwrócić uwage na powołany przez wojewodę białostockiego Karola Kirsta Wojewódzki Teatr Objazdowy, którego celem było szerzenie kultury polskiej i krzewienie piękna mowy w terenie. Teatr wystawiał darmowe spektakle dla mieszkańców w miejscowościach odległych od centrów kulturalnych. Łomżyńskie pisma sporo uwagi poświęcały amatorskiej scenie teatralnej i muzycznej, a to prasowe zainteresowanie zachęcało artystów amatorów do doskonalenia warsztatu, a widzów do uczestnictwa w koncertach i spektaklach. Ciekawą inicjatywą katolickiego tygodnika „Sprawa Katolicka” było powołanie w 1936 r. Biblioteki Dobrych Książek. Redakcja co miesiąc wydawała tanią (za 1zł) książkę $z$ literatury polskiej.

Na prasowych łamach, jak w zwierciadle, odbijały się wszystkie przejawy życia miasta i regionu. $Z$ prasowych szpalt wyłaniał się wielowątkowy obraz mieszkańców. Był w nich portret społeczeństwa zjednoczonego i solidarnego. Tak było w czasie wojny w 1920 r., w czasie organizowania pomocy powracajacym $z$ Rosji reemigrantom, także w obliczu wojennego zagrożenia tuż przed wybuchem II wojny światowej, kiedy mieszkańcy Łomży zbierali pieniądze na samolot i karabin maszynowy. W tych historycznych chwilach bez znaczenia były wcześniejsze podziały ideologiczne społeczeństwa. W prasie był też jednak ukazany obraz łomżyńskiego społeczeństwa podzielonego i skłóconego. Tak było po zamachu majowym w 1926 r., po wyborach w 1928 r. i po opublikowaniu 
głośnego listu pasterskiego przez bp. Stanisława Łukomskiego, który niezadowolony $z$ wyborczego wyniku - zalecał „ukaranie” wiernych odmową święcenia wielkanocnych pokarmów i zakazem odprawiania mszy rezurekcyjnej. O tych wydarzeniach pisała także centralna prasa.

W łomżyńskiej polskojęzycznej prasie prezentowane były różne kwestie (tragiczne, prawne, radosne) dotyczace mieszkańców. Bohaterowie publikacji często byli wymieniani $z$ imienia i nazwiska, choć były też artykuły o zbiorowych i anonimowych bohaterach - organizatorach kwest, imprez kulturalnych, uczestnikach akcji charytatywnych, wieców, nabożeństw, zebrań. Na łamach prasy „gościli” również ci, którzy weszli w konflikt $z$ prawem. Uważny czytelnik mógł się zorientować, które $z$ opisywanych działań popierała prasa, które inspirowała, jak je oceniała. Widoczne było zaangażowanie pism w życie mieszkańców Łomży i regionu. Ujawniało się wykorzystywanie prasy do celów propagandowych, ale też do pełnienia roli edukacyjnej i budzącej aktywność społeczna czytelników. Znaczące było zaangażowanie prasy w różne dziedziny życia, ale decydujący wpływ na społeczeństwo miał Kościół katolicki, który był głównym kreatorem życia politycznego w regionie.

Łomżyńska polskojęzyczna prasa okazała się niezwykle bogatym materiałem badawczym. Dysertacja napisana głównie na jej podstawie jest próbą ukazania wielopłaszczyznowego obrazu Łomży i regionu. Próba, bo każdy $z$ wątków można poszerzyć i rozwinąć. Zarówno temat, jak i źródło pozostają więc otwarte i niewyczerpane. 